\title{
A NEW SPECIES OF BIOMPHALARIA PRESTON, 1910 (GASTROPODA, PLANORBIDAE) FROM THE UPPER CRETACEOUS OF URUGUAY
}

\author{
FERNANDA CABRERA \& SERGIO MARTÍNEZ \\ Departamento de Paleontología, Facultad de Ciencias, Universidad de la República. \\ Iguá 4225, C.P. 11400, Montevideo, Uruguay. \\ fcabrera@fcien.edu.uy,smart@fcien.edu.uy
}

\begin{abstract}
A new fossil species of Biomphalaria Preston is described for the Upper Cretaceous of Uruguay (Queguay Formation). The new species is characterized by a conspicuous spiral ornamentation, a unique character within the genus. This new Biomphalaria species is the third known for the Queguay Formation, in addition to $B$. walteri (Parodiz) and $B$. reversa Cabrera, Martínez $\&$ Norbis. They represent the oldest record of this genus worldwide.
\end{abstract}

Keywords: Biomphalaria, Late Cretaceous, Uruguay.

\section{INTRODUCTION}

Biomphalaria Preston, 1910, is a neotropical and afrotropical genus of freshwater, planorbid snails (Taylor, 1988). Its fossil record ranges from the Late Cretaceous to the present day, being common in Cenozoic lentic freshwater assemblages from South America (Parodiz, 1969; DeJong et al., 2001; De Francesco et al., 2007; De Francesco, 2010; Salvador \& Simone, 2013; Cabrera et al., 2016). This genus is indicative of several environmental parameters, being very useful in paleoecological reconstructions. The populations of Biomphalaria usually live in lentic, shallow and very low energy environments, such as temporary puddles, marshes and shallow lakes, commonly with abundant aquatic vegetation (Cridland, 1967; Pieri et al., 1980; Olazarri, 1981a, 1981b; Bonetto et al., 1982; Vianey-Liaud \& Lancastre, 1986; Ohlweiler \& Kawano, 2001, 2002; De Francesco, 2010; Hassan et al., 2011; Cabrera et al., 2018). A new species is described herein for the limestones of the Upper Cretaceous Queguay Formation, Uruguay.

The Queguay Formation is mainly distributed in two areas within the Uruguayan territory; with outcrops in the northwest, along the margins of the Uruguay River, and others in the Santa Lucía Basin in the south (Figure 1). It is composed by pedogenic calcretes, palustrine limestones, and paleosols (for stratigraphic details see Alonso-Zarza et al., 2011; Martínez et al., 2015). The fossil record of this unit comprises several gastropods, some terrestrial, such as Eoborus charruanus, E. berroi, Bahiensis priscus, Bulimulus klappenbachi, Pupoides gnocco, Succineidae indet. and Clausiliidae indet., and freshwater ones, such as Biomphalaria walteri, B. reversa and Physa sp. Other remains correspond to dinosaur eggshells, hackberry endocarps, rhizoliths, insect nests and pupal chambers, characean gyrogonites and ostracods (Martínez et al., 2001; Verde, 2012; Cabrera, 2015; Cabrera et al., 2018). The molluskan and the paleobotanical fossil records of the Queguay Formation are strikingly similar to the recovered from beds of the Itaboraí Basin in the State of Rio de Janeiro, Brazil (Bergqvist et al., 2009; Salvador \& Simone, 2013). The new species here described, together with Biomphalaria walteri (Parodiz, 1969) and B. reversa Cabrera, Martínez \& Norbis, 2016, represent the oldest record of this genus worldwide (Cabrera et al., 2016; Cabrera et al., 2018). Abbreviations. FCDP-I, Colección de Paleontología de la Facultad de Ciencias, Universidad de la República, Uruguay; mxD, maximum diameter; $\mathbf{m n D}$, minimum diameter; $\mathbf{H}$, height (Figure 2G).

\section{SYSTEMATIC PALEONTOLOGY}

Family PLANORBIDAE Rafinesque, 1815

Subfamily PLANORBINAE Rafinesque, 1815

Biomphalaria Preston, 1910

Type Species. Biomphalaria smithi Preston, 1910 by monotypy.

Biomphalaria manya sp. nov.

(Figures 2-3)

Diagnosis. Biomphalaria with conspicuous spiral ornamentation. Only last three whorls visible in umbilical view. Description. Shell small (mxD 9 to $4 \mathrm{~mm}$ ), subcircular, sinistral. Conspicuous spiral ornamentation in all whorls, parallel to the suture, composed of about 19 primary ribs, three per millimeter, and secondary ribs about three to five between primary ribs. Five rounded, convex whorls in apical view, last one larger than others. Sutures narrow well marked. The last three whorls cover the first ones in umbilical view. Umbilicus occupies about $4 \%$ of shell. Aperture oval, maximum dimension about $46 \%$ of maximum diameter.

Type material. Holotype: FCDP-I 8719, figures 2a, b and c, $\mathrm{mxD} 9.37 \mathrm{~mm}, \mathrm{mnD} 8.11 \mathrm{~mm}, \mathrm{H} 3.51 \mathrm{~mm}$; paratype 1: 


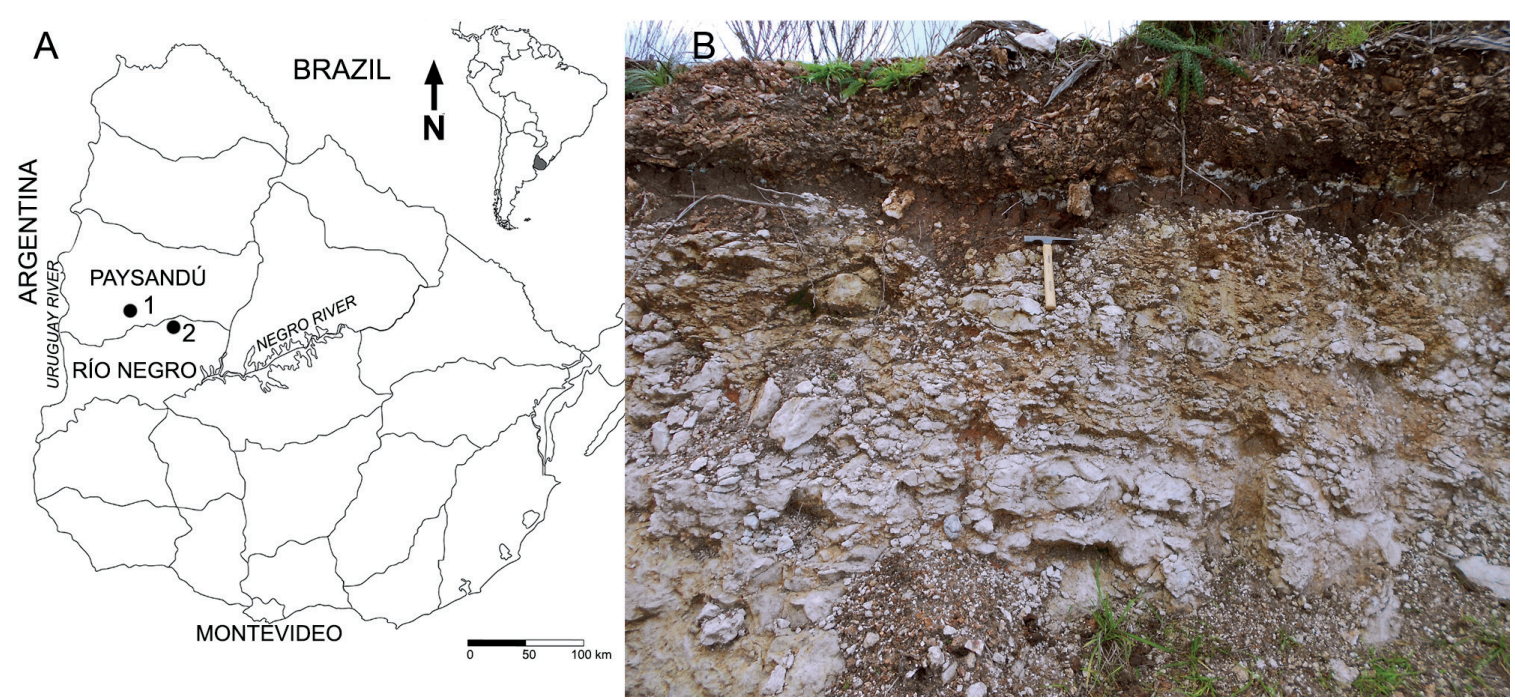

Figure 1. A, map showing the localities where the specimens were collected: 1, proximity of Piedras Coloradas Town, Paysandú Department; 2, nearby Algorta Town, Río Negro Department. B, type locality (nearby Algorta Town, Río Negro Department), on top siliceous bed altered by recent soil formation; below, massive limestone bed, both beds fossiliferous. Length of hammer $=28 \mathrm{~cm}$.

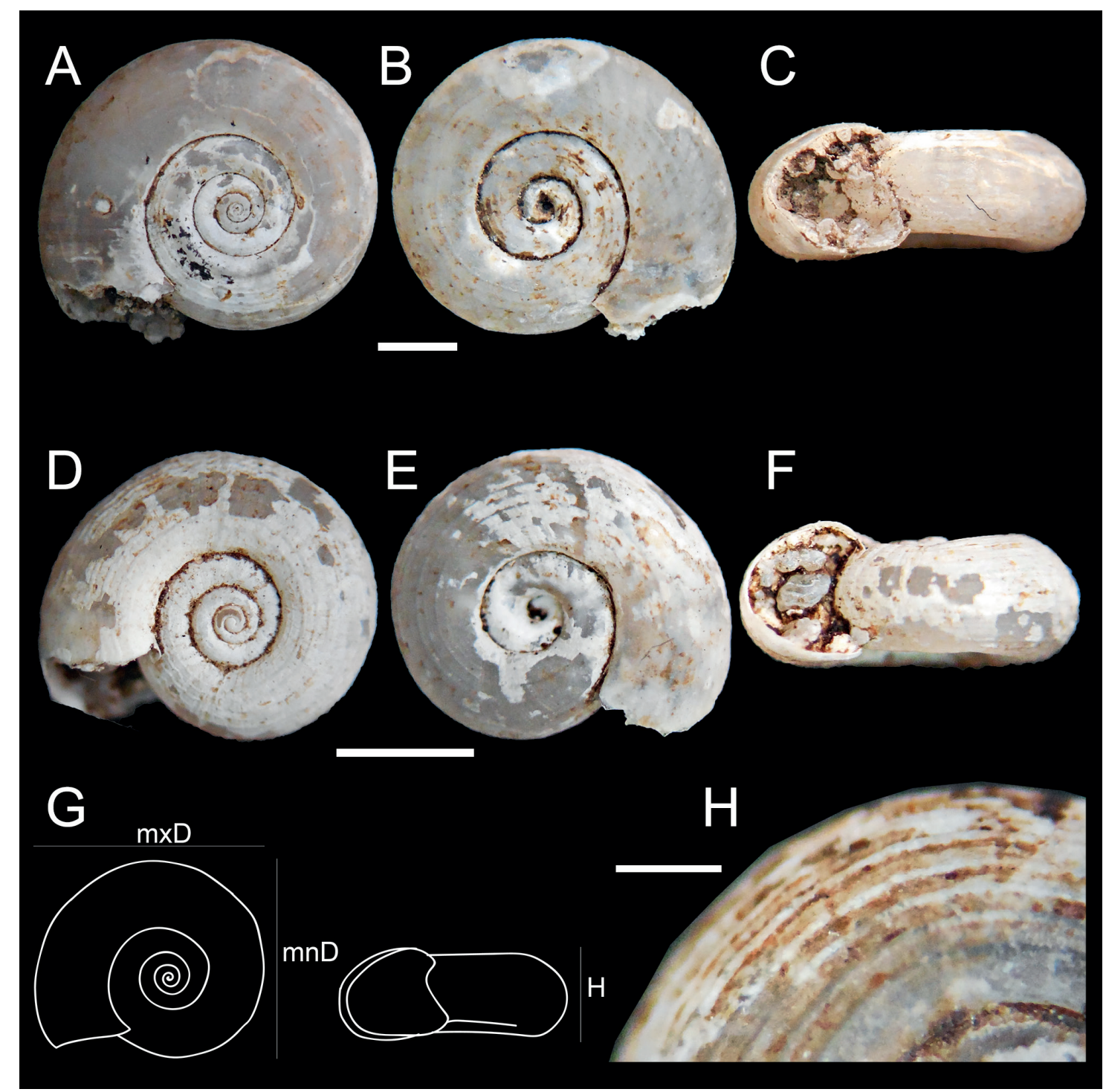

Figure 2. Biomphalaria manya sp. nov. A-C, FCDP-I 8719 holotype, apical view (A), umbilical view (B), apertural view (C). D-F, FCDP-I 8720 paratype 1, apical view (D), umbilical view $(\mathbf{E})$, apertural view $(\mathbf{F})$. G, measures; H, detail of the ornamentation. Abbreviations: mxD, maximum diameter; mnD, minimum diameter; $\mathbf{H}$, height. Scale bars: $\mathrm{A}-\mathrm{F}=2 \mathrm{~mm} ; \mathrm{H}=1 \mathrm{~mm}$. 


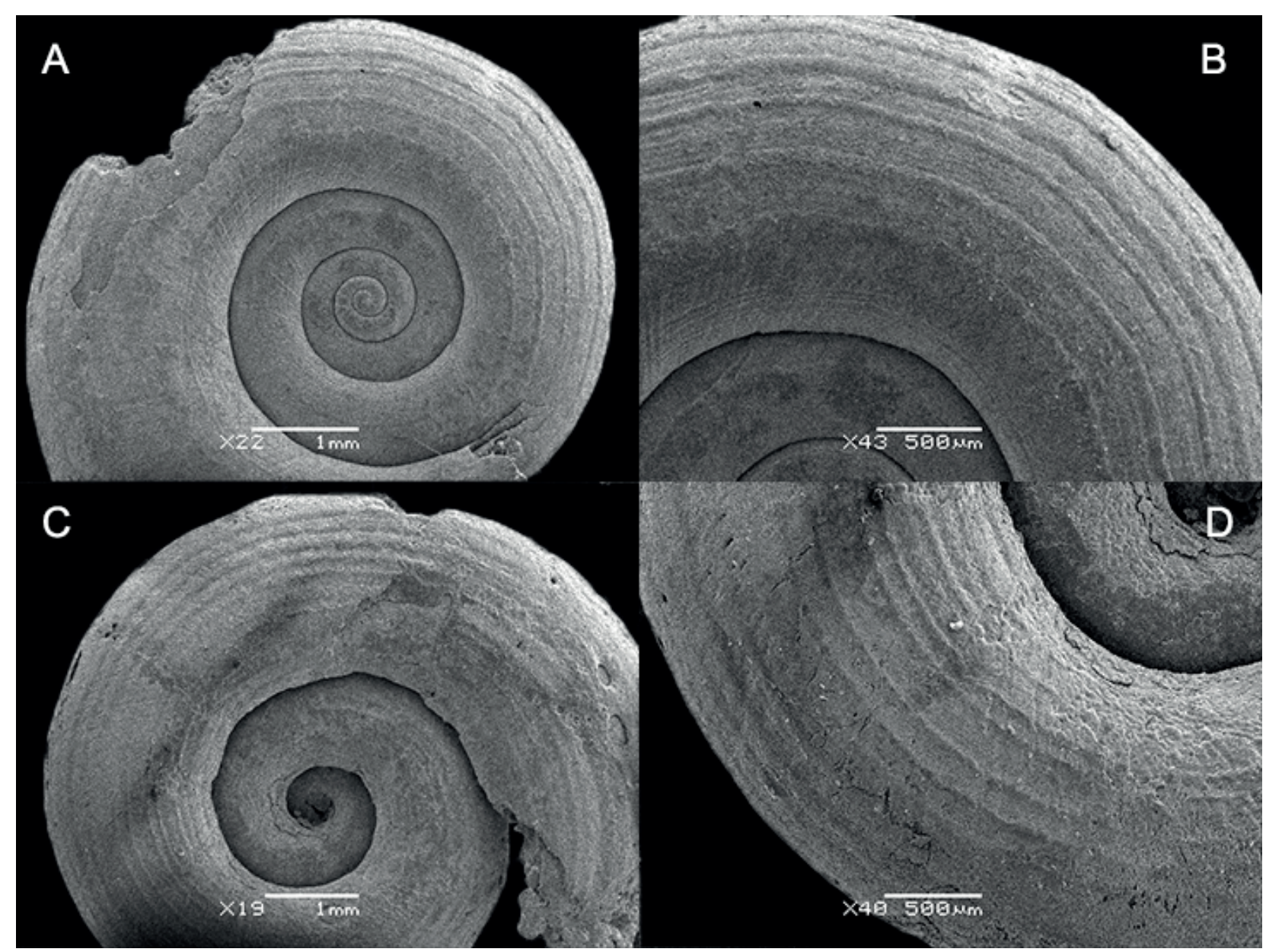

Figure 3. Scanning Electron Microscope (SEM) images of two specimens of Biomphalaria manya sp. nov. FCDP-I 7218. A, apical view; B, detail of the ornamentation in apical view, with secondary ribs between the primary ribs; $\mathbf{C}$, umbilical view; $\mathbf{D}$, detail of the ornamentation in umbilical view.

FCDP-I 8721, figures 2d, e and f, $\mathrm{mxD} 5.16 \mathrm{~mm}, \mathrm{mnD} 4.28$ $\mathrm{mm}, \mathrm{H} 2.1 \mathrm{~mm}$.

Type locality. Nearby Algorta Town, Río Negro Department. $32^{\circ} 28.640^{\prime} \mathrm{S}, 057^{\circ} 24.660^{\prime} \mathrm{W}$ (Figure 1B).

Other material. 75 specimens, FCDP-I 7218, 7228, 8720.

Geographic and stratigraphic range. Nearby Algorta Town, Río Negro Department; proximities of Piedras Coloradas Town, Paysandú Department, Uruguay. Queguay Formation, Upper Cretaceous.

Etymology. Dedicated to C.A. Peñarol, "Manya", inspired by the striped ornamentation of the shell.

Comparative remarks. The diagnosis of the genus Biomphalaria by Preston (1910) is: "Shell subdiscoidal, planulate with concave spire, last whorl very large; umbilicus open, but shallow; aperture gaping; labium greatly receding below". With respect to the ornamentation, Paraense (1975) adds to the diagnosis "... whorls ornate only with growth striae". Given the ornamentation of this new species, the original diagnosis (Preston, 1910) is more suitable than the revision by Paraense (1975). The major difference between Biomphalaria manya sp. nov. and the other species of the genus is the notorious spiral ornamentation of the shell, consisting of about 19 primary ribs with secondary ribs only visible by means of a Scanning Electron Microscope
(SEM) (Figures 2H, 3). In addition, and regarding the other Biomphalaria species from the Queguay Formation, B. manya sp. nov. differs from $B$. walteri by the rather smaller shell size of the new species. Besides, in umbilical view $B$. walteri shows only the latest two whorls, while in $B$. manya sp. nov. the last three whorls are visible. With respect to $B$. reversa, this species is dextrally coiled, while $B$. manya sp. nov. has a sinistral shell. In addition, $B$. manya sp. nov. is larger than $B$. reversa. In apical view, the whorls of $B$. reversa maintain a uniform distance between each other, while in the new species the whorls gradually increase their distance towards the aperture. In umbilical view $B$. reversa shows only the last two whorls, while B. manya sp. nov. shows the last three whorls.

\section{ACKNOWLEDGMENTS}

To M. Verde and the Quebracho team (A. Batista, N. Batalla, F. Montenegro, and G. Roland), who helped in field work. To L. Vivanco who helped in laboratory work. To Agencia Nacional de Investigación e Innovación (ANNI Project FCE 3_2011_1_5702) and PEDECIBA Biología for financial support. To A. Rojas and two anonymous reviewers who made suggestions that improved the paper. 


\section{REFERENCES}

Alonso-Zarza, A.M.; Genise, J.F. \& Verde, M. 2011. Sedimentology, diagenesis and ichnology of Cretaceous and Palaeogene calcretes and palustrine carbonates from Uruguay. Sedimentary Geology, 236:45-61. doi:10.1016/j.sedgeo.2010.12.003

Bergqvist, P.L.; Mansur, K.; Rodrigues, M.A.; Rodrigues-Francisco, B.H.; Perez, R. \& Beltrão, M.C. 2009. Bacia São José de Itaboraí, RJ. Berço dos mamíferos no Brasil. In: M. Winge; C. Schobbenhaus; C.R.G. Souza; A.C.S. Fernandes; E.T. Queiroz; M. Berbert-Born \& D.A. Campos (eds.) Sítios geológicos e paleontológicos do Brasil, DNPM/CPRM, Comissão Brasileira de Sítios Geológicos e Paleobiológicos (SIGEP), p. 413-432.

Bonetto, A.A.; Bechara, J.A. \& Tassara, M.P. 1982. Los moluscos de la familia Planorbidae en el área del Río Paraná medio. Physis, 41:1-6.

Cabrera, F. 2015. Paleobiodiversidad y paleoecología de moluscos continentales. El Cretácico tardio - Paleógeno de Uruguay como caso de estudio. Programa de Desarrollo de las Ciencias Básicas, Universidad de la República, Tesis de Maestría, 125 p.

Cabrera, F.; Martínez, S. \& Norbis, W. 2016. Recognition of Biomphalaria species (Gastropoda: Planorbidae) using the spiral growth variability, with description of a new fossil species. The Nautilus, 130:5-12.

Cabrera, F.; Martínez, S. \& Verde, M. 2018. Continental Late Cretaceous gastropod assemblages from Uruguay. Paleoecology, age, and the oldest record of two families and a genus. Historical Biology (in press). doi:10.1080/08912963.2018.1471478

Cridland, C.C. 1967. Resistance of Bulinus (Physopsis) globosus, Bulinus (Ph.) africanus, Biomphalaria pfeifferi and Lymnaea natalensis to experimental desiccation. Bulletin of the World Health Organization, 36:507-513.

De Francesco, C.G. 2010. Moluscos y paleoambientes del centrooeste de Argentina durante el Cuaternario. In: M. Zárate; A. Gil \& G. Neme (eds.) Condiciones paleoambientales y ocupaciones humanas durante la transición Pleistoceno-Holoceno y Holoceno de Mendoza, Sociedad Argentina de Antropología, p. 151-174.

De Francesco, C.G.; Zárate, M.A. \& Miquel, S.E. 2007. Late Pleistocene mollusc assemblages and inferred paleoenvironments from the Andean piedmont of Mendoza, Argentina. Palaeogeography, Palaeoclimatology, Palaeoecology, 251:461469. doi:10.1016/j.palaeo.2007.04.011

DeJong, R.J. et al. 2001. Evolutionary relationships and biogeography of Biomphalaria (Gastropoda: Planorbidae) with implications regarding its role as host of the human blood fluke, Schistosoma mansoni. Molecular Biology and Evolution, 18:2225-2239. doi:10.1093/oxfordjournals.molbev.a003769

Hassan, G.S.; De Francesco, C.G. \& Peretti, V. 2011. Distribution of diatoms and mollusks in shallow lakes from the semiarid Pampa region, Argentina: their relative paleoenvironmental significance. Journal of Arid Enviroments, 78:65-72. doi:10.1016/j. jaridenv.2011.11.002

Martínez, S.; Veroslavsky, G. \& Cabrera, F. 2015. Calizas del Queguay: un enfoque hacia la Arqueología. Revista de Antropología del Museo de Entre Ríos, 1:1-10.
Martínez, S.; Veroslavsky, G. \& Verde, M. 2001. Paleoecología de los paleosuelos calcáreos fosilíferos ("Calizas del Queguay" Paleoceno) de las regiones sur y litoral oeste del Uruguay. In: CONGRESO LATINOAMERICANO DE GEOLOGÍA, 11, 2001. Actas, Montevideo, 219.

Ohlweiler, F.P. \& Kawano, T. 2001. Effects of the Desiccation on Biomphalaria tenagophila (Orbigny, 1835) (Mollusca) infected by Schistosoma mansoni Sambon, 1907. Memórias do Instituto Oswaldo Cruz, 96:737-749. doi:10.1590/S007402762001000500029

Ohlweiler, F.P. \& Kawano, T. 2002. Biomphalaria tenagophila (Orbigny, 1835) (Mollusca): adaptation to desiccation and susceptibility to infection with Schistosoma mansoni Sambon, 1907. Revista do Instituto de Medicina Tropical de São Paulo, 44:191-201. doi:10.1590/S0036-46652002000400003

Olazarri, J. 1981a. Biomphalaria tenagophila (d'Orbigny) 1835 (Moll. Gastr.) en la zona de Salto Grande. I. Ambientes de cría. Comunicaciones de la Sociedad Malacológica del Uruguay, 5:321-345.

Olazarri, J. 1981b. Biomphalaria tenagophila (d'Orbigny) 1835 (Moll. Gastr.) en la zona de Salto Grande. II. Factores abióticos que afectan sus poblaciones. Comunicaciones de la Sociedad Malacológica del Uruguay, 5:391-417.

Paraense, W.L. 1975. Estado atual da sistemática dos planorbídeos brasileiros. Arquivos do Museu Nacional, 55:105-128.

Parodiz, J.J. 1969. The Tertiary non-marine Mollusca of South America. Pittsburgh, Carnegie Museum, 242 p. (Annals 40). doi: $10.2307 / 2412214$

Pieri, O.S.; Raymundo, J.S. \& Jurberg, P. 1980. Estudos sobre o comportamento dos planorbideos. II. Enterramento de Biomphalaria glabrata (Say, 1818) como meio de proteção contra a dessecação. Memórias do Instituto Oswaldo Cruz, 75:83-88. doi:10.1590/S0074-02761980000100008

Preston, H.B. 1910. Additions to the non-marine molluscan fauna of British and German East Africa and lake Albert Edward. The Annals and Magazine of Natural History, 35:526-536.

Salvador, R.B. \& Simone, L.R.L. 2013. Taxonomic revision of the fossil pulmonate mollusks of Itaboraí Basin (Paleocene), Brazil. Papéis Avulsos de Zoologia. Museu de Zoologia da Universidade de São Paulo, 53:5-46. doi:10.1590/S003110492013000200001

Taylor, D.W. 1988. Aspects of freshwater mollusc ecological biogeography. Palaeogeography Palaeoclimatology Palaeoecology, 62:511-576. doi:10.1016/0031-0182(88)90071-5

Verde, M. 2012. Icnología de la Formación Asencio y las “Calizas Del Queguay”. Programa de Desarrollo de las Ciencias Básicas, Universidad de la República, Tesis de doctorado, 204 p.

Vianey-Liaud, M. \& Lancastre, F. 1986. Weight loss and survival of Biomphalaria glabrata deprived of water. Memórias do Instituto Oswaldo Cruz, 81:221-224. doi:10.1590/S007402761986000200012

Received in 23 May 2018; accepted in 23 October 2018. 